\title{
Modernism in Joyce's A Portrait of the Artists as a Young Man
}

\author{
Mutasim Yasin Mohammad Mahadin Mohd Nazri Latif Azmi \\ Universiti Sultan Zainal Abidin
}

\begin{abstract}
This paper investigated modernist in Joyce's a portrait of the artists as young man. The findings of the study showed that Joyce did not tell a story with a coherent plot and a traditional beginning, middle, and end. Instead of that he used the stream of consciousness technique to select crucial moments in the life of Dedalus. By doing that, Joyce refused the chronologically ordered plot that characterized most of the novels in the nineteenth century. This technique of narration led to a revolution in the form of novels and opened the door to a deeper and more comprehensive study of the inner parts of characters. Also, the results of the study indicated that the stream of consciousness and the interior monologue built the novel through the representation of the ideas, dreams and imaginations of the major character. Finally, the book can be read as both a representation of Joyce's life and a declaration of liberty from all the conventions and norms that controlled the novel as a literary form.
\end{abstract}

Keywords: Modernist, Joyce, Portrait, Artist and Literary Movement.

DOI: $10.7176 /$ JLLL/54-04

Publication date:March $31^{\text {st }} 2019$

\section{Introduction.}

The Irish writer and poet James Joyce is undoubtedly considered as one of the leaders in the modern fiction. He - in addition to Virginia Woolf - played a significant role in the process of forming the modern fiction in its new form. Joyce presented many great works in both verse and prose and contributed with his masterpieces in the literature of the twentieth century. The Irish writer is best known for his contributions in the advancement of the modern novel. In his works he refused to abide by the conventional norms of the classical novel. Instead he portrayed his works using new techniques in narration such as the stream of consciousness and the interior monologue. The new techniques of narration were blended with the aspects of realism, naturalism and symbolism and combined with the psychological presentation of the characters.

Joyce presented many masterpieces through the course of his literary journey. In his novels he projected the inner life of his protagonists concentrating on depicting their feelings, ideas, intuitions, and inner suffering. He wanted from his readers to sail through the turmoil of the character's personal desires and dreams, and to see the character while he is portrayed truly through his ideas and feelings. In his masterpiece $A$ Portrait of the Artist as a Young Man; Joyce presented the life and the development of an artist from his tender years until maturity. The novel is considered as a landmark in the history of literature and it contributed in the process of giving Joyce his deserved place as one of the greatest writers in the modern literature. In this paper the concentration will be focused on this novel as a work characterized by the artistic and literary techniques of the modern fiction. In the first part of the paper a description will be introduced to the history and the characteristics of modernism. A general and summarized presentation of the novel follows the first part of the research to introduce the story and the plot of the novel to the reader. The major part of this paper will shed some light on the modern aspects of this novel and on how did Joyce portray this painting using the colours and styles of the modern movement in literature. It is hoped that this paper will project to the reader in an honest and objective way one of the most important works that ever written in the course of the twentieth century. The paper will also project to the reader some of the creativity and literary talent of Joyce. In addition to what has been mentioned, an introduction shall be presented to A Portrait of the Artist as a Young Man, as a novel that conforms to both the traditions of the modern fiction and the resourcefulness of Joyce who placed himself between the greatest writers of his time.

\section{What is Modernism?}

The First World War is considered as the leading force behind the initiation of the modern period in literature. The world "Modern" is used in literature to distinguish the conventions followed by the literary works in the twentieth century from the conventions that depicted the literature of the nineteenth century. As a result of the suffering and misery that people faced during the horrors of the First World War, the world lived in a phase of chaos and separation. People who were terrified by the ugliness of the war started to question all the old systems of beliefs that depicted their lives and they entered a state of denial and disbelief. The spiritual emptiness that colored the life of people during the first half of the twentieth century presented a significant factor in the development of the modern theory in literature. Many artists were enthusiastic to the idea of projecting the ordinary individual and the hardships that he faces in his life. Modern writers were also affected by the heavy burden of the war and consequently depicted their literature with the psychological and physical sufferings of those who lived through and after the course of war. Modern writers presented the idea that people in the 
twentieth century had become alienated in their communities. They refused the old systems of beliefs and lived the days of their lives looking for new ones. As a result of what has been mentioned, the individual is constantly portrayed through modern works as alienated, isolated, and fight aimlessly with the powers of nature that controlled both his life and future. The dreams of the individuals are seen as hopeless and his struggle to prove his identity is usually resulted in his failure and breakdown.

One of the most typical characteristics of modernism is the experimental quality of literature. This feature came as a result of the condition of living in a modern life that is characterized by the scientific, industrial and technological changes. So modernism is characterized by the experimentation of form. This style of writing opens to the writer the ability to adopt the quality or style of writing that suites his desires in the process of writing his work. By refusing most of the conventions inherited from the nineteenth century, modern fiction rejected the chronologically ordered plot. Instead, it used the freedom of experimentation to initiate new styles of narrating like the stream of consciousness and the interior monologue. Modern literature also broke most of the bonds and conventions of Realism and Romanticism. For example, it reflected a clear rejection of the optimism apparent in the Victorian literature, and replaced it with a gloomy and skeptic portrait of life. The uncertainty and skepticism of modern literature depicted the human being as hopeless, helpless and useless in his life. He is also presented as leading a struggle to free himself from the bonds of community that tied his ability to think and behave according to his own desires.

Modernism was not mainly interested in presenting the historical and social aspects of any community. But the concentration was mainly shifted from the outer part of the characters to the inner part giving a great importance to their inner experiences and identities. This concentration as mentioned earlier led to the development of new techniques of narrating the events of the story such as the stream of consciousness and the interior monologue. These styles of narrating exposed to the reader the full presentation of the character's ideas, intuitions, thoughts, desires and dreams in a way that gave to the character the opportunity to introduce himself to the reader rather than being introduced by the narrator. Other techniques like the flash back were also used to give to the reader a complete picture of the character. As a result of this concentration on the inner part of the human being, many psychological schools of criticism sprang up to present a deeper study of the human's psyche. Freud- for instance- contributed in the forming of the psychoanalytical theories in literature. He and other writers presented the character in modern literature as a victim of many inaccessible forces in nature that manipulated his life and existence. The character is not shown as the center of the universe but as an inferior creature in a struggle to prove himself and to find his lost identity.

Modern fiction was also characterized by many other characteristics in both form and style. The open form as mentioned earlier was a product of the experimentation and the total refusal of the conventions inherited from the nineteenth century. The language of modern works was also altered by this upheaval in literature. The modern text for instance was characterized by the use of colloquial language rather than formal one to emphasize the reality and credibility of the incidents. This language was also enriched with images and symbols as typical and frequent literary techniques with the process of borrowing from other cultures and languages. Many other elements of modernism were frequent and necessary to the building process of the literary work like the discontinuous narrative and the sense of overwhelming technologies that changed the $20^{\text {th }}$ century. But one of the most important characteristics of modern works was the absence of a heroic figure in these works which was replaced by the weak and defeated human being who lived as alienated in the absurdity of his life.

In the light of what has been mentioned it is obvious that the modern novel was preoccupied through the course of its development with the complexities of the form, the representation of inner state of the character, the sense of disorder, chaos and alienation, and the freeing narrative style from the classical conventions of the plot.

\section{The Portrait.}

A Portrait of the Artist as a Young Man is an autobiographical novel. The story of this novel narrates the years of development in the life of an artist from childhood to the artistic maturity. Stephen Dedalus is an Irish artist who lived in Ireland at the beginning of the twentieth century and tried through the course of his life to free himself from the constraints of his religion, family and nationality. He changed himself by his artistic maturity from an individual who was victimized by the forces of nature to a person in control of his life and his destiny.

The story started with Dedalus as a little child who experienced the events of his everyday life through the mind of immature and inexperienced spontaneity. The first part of the novel counted for the years before school when Dedalus presented to the reader his basic fears and joys. The reader is transformed after that to the years of the artist's youth at Clongowes; the place where the character of Dedalus was developed from a fearful and confused boy who was constantly bullied by his colleagues to a brave and confident student who even protested against the injustice of the prefect. Through this part of the novel the reader is also exposed to the themes of Christianity and nationalism in the life of Dedalus. Dedalus was invited to the Christmas dinner at his father's house where a great quarrel occurred between the catholic members of his family over the independence of Ireland from Britain. This fight and other incidents in the story shed some light on current psychological identity 
of Dedalus as an Irish and catholic boy who was confused about language, politics and religion.

The story of the novel introduced to the reader the years in which the artist's personality was formed. The concentration was given through these years to the struggle in which Dedalus tried to free himself from the bonds that constrained his identity and his artistic freedom. Stephen for instance was tortured by the psychological effect of his sin. He committed the sin of adultery with a prostitute and as a result lived in a long and continuous phase of agony. His commitment to Christianity prohibited him from satisfying his lust, but his sexual eagerness drove him to the path of sins. It is obvious here that Joyce presented the dilemma of sin and repentance in the life of the young artist to project to the reader the bonds and constraints of Christianity that restrained the life of the young artist Stephen Dedalus as well as the life of James Joyce.

The maturity of Stephen was confirmed by his growing doubt about all the forces that controlled his youth. His doubt and his ambition to become an artist provoked him to declare a revolution against all the factors that restrained him and to refuse to work as a priest in the devout society of Christianity.

At the end of the novel Dedalus experienced a state of total isolation. He knew that his artistic identity should be formed away from the bonds of his society and his family. He declared his religious independence by refusing to work as a priest. He also declared his political freedom by expressing his distaste for the Irish nationalism. By doing that, Dedalus also declared his distance from family, religion and nationality and his ability to start a mission for artistic perfection away from his motherland Ireland.

\section{The Modern Portrait.}

A Portrait of the Artist as a Young Man is considered as one of the most important novels that introduced to the reader the modern trends in the art of fiction. All the aspects of the novel like the title, the style, the narrative, the plot, and even the theme portrayed a unique image of the combination between the modern aspects of fiction and the unique style of Joyce. This combination presented to the world of literature and the English literature in particular one of the most memorable texts in the history of fiction.

\section{The Title.}

The title of Joyce's novel represents a key to his intention in writing $\underline{\text { A Portrait. }}$. The novel is a portrait, one of many that could have been painted. The use of the indefinite article "a" is a clear indication that Joyce did not want to give himself the credit of presenting the life of the artist in a comprehensive way. He indirectly tells his readers that the novel is no more than an attempt to depict the life of Dedalus from the writer's own perspective. Joyce indicated that it was only one portrait of many that could have been portrayed depending on the perspective from which the reader looks at the artist. He gives his readers the ability to see and judge the life of Dedalus by exposing to them the inner part of the character and excluding himself from narrating the events of the story by using his own voice. The world "Portrait" indicates the artistic level that Joyce used in creating the novel. He represented himself as an artist who tried to draw a picture of Dedalus using his tools of language and creativity instead of the colours and creating a masterpiece in the art of fiction. The novel focuses on the growth of the protagonist's mind and personality and his quest to liberate himself from the bonds that tied his dreams and desires. The title reflects the experiences of the protagonist in his youth and how he faced the surrounding world to free himself. It is clear that the concentration of this work is on the personality and psychology of the artist. This concentration is a style followed by modern novelists that through Freud and his theories placed the importance on the inner part of the character and his personality.

\section{B. The Artist and the Novel.}

A Portrait is a Bildungseroman that it concentrates on the life and the development of the major character. It can also be considered as a Kunstlerroman since the major character is an artist who experienced through the novel the years of forming his personality. The story of the novel narrates - as mentioned previously - the life of an artist from his tender years to the years of maturity. It also concentrates on the spiritual liberation of Stephen Dedalus from the bonds of family, nationality, and religion, which formed the major characteristics of his society. Through the course of the novel Dedalus was portrayed as an alienated and isolated creature from his surroundings. In his childhood the young Dedalus was presented by Joyce as small and weak, not good at games, bullied constantly by bigger boys, unable to understand their jokes and teasing, and desperately homesick. Joyce portrayed the young artist in his childhood and youth as a lost person. For him the world was an enigmatic place, and people were strange to him. Even his colleagues at school were bigger and stronger than him. This situation created a sense of loss and alienation in the mind of the little Dedalus. He suffered from a case of loss of identity that was strong and forced Dedalus to remind himself constantly of who he was and what was his name:

"Stephen Dedalus is my name,

Ireland is my nation.

Clongowes is my dwelling place

And heaven my expectation (Joyce 9)" 
The sense of alienation is one of the modern features in literature. The character is usually presented as alienated and isolated from the world he lives in. Dedalus suffered from this feeling in the novel. His inner life and his environment were alien to each other and that was skillfully portrayed by Joyce when Dedalus as mentioned earlier constantly reminded himself of his place in the universe by writing the following lines on his books:

"Stephen Dedalus
Class of Elements
Clongowes Wood College
Sallins
County Kildare
Ireland
Europe
The World
The Universe. (Joyce 8)"

Dedalus also represented the modern character or the (anti hero) in the novel. He was portrayed as a weak and small character unable to practice what his colleagues in the school were able to do:

"He kept on the fringe of his line, out of the reach of the rude feet,

feigning to run now and then. He felt his body small and weak amid the throng of players and his eyes were weak and water (Joyce 2)"

It is obvious through what has been mentioned that Dedalus was a clear example of the modern character in literature. By his weakness and the sense of isolation that lived with him, Dedalus experienced the theme of alienation, exile and estrangement that colored the life of people in the twentieth century:

"All the boys seemed to him very strange. They had all fathers and mothers and different clothes and voices. He longed to be at home and lay his head on his mother's lap (Joyce 6)"

Through naturalism, modern fiction usually presents the man as fundamentally no more than a specialized animal. This animal spends his life in a hopeless struggle with the forces of nature such as heredity and environment. He is also driven by his most primitive desires such as hunger and sexuality. In the novel Dedalus suffered from his agitating lust that drove him to commit the sin of adultery with a prostitute. He was forced by his sexual hunger to act like an animal in his search to satisfy his appetite:

"Such moments passed and the wasting fires of lust sprang up again.

The verses passed from his lips and the inarticulate cries and the unspoken brutal words rushed forth from his brain to force a passage. His blood was in revolt. He wandered up and down the dark slimy streets peering into the gloom of lanes and doorways, listening eagerly for any sound. He moaned to himself like some baffled prowling beast. He wanted to sin with another of his kind, to force another being to sin with him and to exult with her in sin (Joyce 82)"

Stephen Dedalus was also presented in many parts of the novel as fighting aimlessly with life. He was caged by the forces of his society and wanted to free himself from these forces. To be an artist he had to liberate himself from the norms, traditions and the values that controlled his life. As a result Dedalus isolated himself from his family, friends and society but that led to a burning feeling of isolation and alienation:

"He saw clearly too his own futile isolation. He had not gone step

Nearer the lives he had sought to approach nor bridges the restless shame and rancour that divided him from mother and brother and sister. He felt that he was hardly of the one blood with them but stood to them rather in the mystical kinship of fosterage, fosterchild and foster brother (Joyce 81)"

Joyce also reflected through Dedalus the meaningless and absurdity of life. For him and for many modern writers life was always seen as a meaninglessness tragedy that crushed all the dreams and aspirations of people. Their lives were continuous struggles with the universe and their dreams were oppressed and humiliated by the cruel reality of their lives:

\footnotetext{
"How foolish his aim had been! He had tried to build a breakwater of order and elegance against the sordid tide of life without him and to dam up, by rules of conduct and active interests and new filial relations, the powerful recurrence of the tides within him. Useless. From without and from within the water had flowed over barriers: their tides began once more to jostle fiercely above the crumbled mole (Joyce 81)"
} 


\section{The Narrator and the Plot}

Like many of the novels that preceded it, A Portrait of the Artist as a Young Man was written in the third person narrator. But it is obvious that the style of narrating is a combination between the conventional third person narrative and the modern style of narrating. Joyce's style of narrating is very different from the omniscient narrator that was used in the nineteenth century. The narration of the story was skillfully drawn through the techniques of the stream of consciousness and the interior monologue. Using this style of narration enabled Joyce to convey all the contents of his character's mind, memory, feelings, intuitions and thoughts. So the reader was given the chance to see Dedalus from inside and to understand him more clearly by reading his thoughts and hearing him thinking in a loud voice of simple things like the idea of kiss:

"He still tried to think what was right to answer. Was it

right to kiss his mother or wrong to kiss his mother?

What did that mean, to kiss? You put your face up

like that to say good night and then his mother put

her face down. That was to kiss. His mother put her

lips on his cheek; her lips were soft and they wetted

his cheek; and they made a tiny little noise: kiss.

Why do people do that with their two faces? (Joyce 8)"

Joyce did not only use the stream of consciousness technique because he wanted to expose the inner parts of his character. But he also wanted to concentrate on one single character. Since the novel is no more than a narration to the life of Stephen Dedalus, the focus will be ultimately on him. All the events and incidents were projected and exposed through his mind and all the characters were introduced according to their relation to the young artist. Consequently, it is Dedalus who portrayed this world by his experiences and we - as readers - are only allowed to see this world through the stream of his consciousness. Whether this world is a simple presentation of what a kiss means or if it is an imagination of a funeral we are only experiencing it in relation to Dedalus:

"He wondered if he would die. You could die just the same on a sunny day. He might die before his mother came. Then he would have a dead mass in the chapel like the way the fellows had told him it was when little had died. All the fellows would be at the mass, dressed in black, all with sad faces. Wells too would be there but no fellow would

look at him. The rector would be there in a cope of black and gold there would be tall yellow candles on the alter and round the catafalque. And they would carry the coffin out of the chapel slowly and he would be buried in the little graveyard of the community off the main avenue of limes. And Wells would be sorry then for what he had done. And the bell would toll slowly (Joyce 16)"

In his style of narration, Joyce did not concentrate on the exterior details or the action of the novel. He presented a limited and focused narration that replaced the point of the concentration from the society to the individual. He also refused the classical plot and replaced it with fragmented images from the life of the major character with gapes in time. This replacement enhances the emphasis on the life of Dedalus and rejects the lengthy description of the action.

\section{The Language and the Style.}

Any modern work could be depicted by images and symbols as a typical and frequent literary technique. In $\underline{A}$


images, and epiphanies:

"A girl stood before him in midstream, alone and still, gazing out to sea.

She seemed like one whom magic had changed into the likeness of a strange and beautiful seabird. Her long slender bare legs were

delicate as a crane's and pure save where an emerald trail of seaweed had fashioned itself as a sign upon the flesh. Her thighs, fuller and soft hued as ivory, were bared almost to the hips where the white fringes of her drawers were like feathering of soft white

$$
\text { down (Joyce 144-45)" }
$$

Joyce used many repeated images to enhance the artistic level of his writing. Images of birds, water and death were repeatedly presented. He used the image of birds to suggest Stephen's flight from the middle class with its materialistic concerns. The image of water represented the unpleasant aspects of Stephen's physical and spiritual environment while the image of death portrayed his emotional transform. The language of the novel was used in a realistic way to reflect the development of Dedalus intellectually from the immaturity of childhood to the 
artistic wisdom of manhood. At the beginning of the story Joyce used simple vocabularies and imitated the style of a children's story because the main character of the story and the narrator was in his childhood:

"Once upon a time and a very good time it was there was a moocow coming down along the road and this moocow that was coming down along the road met a nicens little boy named baby tuckoo....(Joyce 1)".

Stephen Dedalus was a child in this part. So the language, syntax and diction reflect the immaturity of the narrator. But the language becomes more sophisticated with the maturity of the narrator who changed from the discussion of children's stories to the philosophical discussions of art and aesthetics. The vocabulary and syntax were also changed to be more mature. It is also noticed that Joyce implied the modern technique of borrowing from other cultures and languages, and that was obvious in the repeated French or Greek phrases or the story of the Greek architect Daedalus.

Joyce also used unusual punctuation in his novel. He wanted his novel to break down all the norms of the conventional novel even in punctuation. He omitted the quotation marks and used instead of them a long dash at the beginning of paragraphs where he presented speeches of characters. This odd style of punctuating prevented the reader from directly knowing who was speaking and mixed the speeches of the characters in the mind of the reader. Joyce used this style intentionally to represent the flow of the ideas and thoughts as they passed through the mind of a character.

\section{E. The Themes.}

Joyce discussed many themes in his novel as the artist and the society, the coming of age, God and religion and the nature of sin. Most of these themes are not modern ones. But Joyce used his unique style and techniques to combine between the conventional themes and the modern style of writing. Joyce for instance had projected the theme of sin and repentance in Christianity but he manipulated the theme to reflect not only the conventional struggle between good and evil, but also the struggle of Dedalus with the bonds of religion and his desire to free himself from the religious constraints of the Catholic Church.

\section{Conclusion.}

Through the course of this paper an effort has been made to shed some light on one of the most important works in the history of the modern fiction. The paper tried to count for the modern aspects in $A$ Portrait of the Artist as a Young Man. The experienced reader will conclude that Joyce did not tell a story with a coherent plot and a traditional beginning, middle, and end. Instead of that he used the stream of consciousness technique to select crucial moments in the life of Dedalus. By doing that, Joyce refused the chronologically ordered plot that characterized most of the novels in the nineteenth century. This technique of narration led to a revolution in the form of novels and opened the door to a deeper and more comprehensive study of the inner parts of characters. The aim of this paper - as might have been noticed - was to study Joyce's novel as an example of the fiction in the twentieth century. Consequently, the paper was divided into different parts in which most of the construction's units of the novel were discussed. The discussion started from the title in which Joyce emphasized his intention in presenting a novel that concentrated on the inner part of the hero, and his psychological identity. This concentration was fully exposed in the projection of Stephen Dedalus and his artistic ambition. In the narrative style of the novel, the stream of consciousness and the interior monologue built the novel through the representation of the ideas, dreams and imaginations of the major character. This was also mingled with the syntax and diction of the novel that ranged from the childlike speech to the sophisticated language depending on the age and experience of Dedalus.

It is also obvious through what has been mentioned that the deep study of this novel is equivalent to the deep study of Joyce's character and life. He skillfully combined his artistic creativity and his literary talent to produce this masterpiece that dwelled in the memory and imaginations of many of his readers. Finally, the book can be read as both a representation of Joyce's life and a declaration of liberty from all the conventions and norms that controlled the novel as a literary form. Many years after its publication, A Portrait of the Artist as a Young Man continues to be regarded as one of the central and most valuable texts in literature of the twentieth century and in the history of modernism as a literary movement.

\section{References}

Blades, John. How to Study James Joyce. Great Britain: Macmillan, 1996.

Deming, Robert H. James Joyce: The Critical Heritage. London: Routledge, 1970.

Goldman, Arnold. The Joyce Paradox: Form and Freedom in His Fiction. London: Routledge, 1966.

James Joyce Today: Essays on the Major Works. Ed. Thomas E. Staley. USA: Indiana UP, 1966.

Jones, William Powell. James Joyce and the Common Reader. USA: Oklahoma UP, 1955.

Joyce, James. A Portrait of the Artist as a Young Man. London: York, 2002. 
Levin, Harry. James Joyce: A Critical Introduction. London: Latimer Trend, 1960.

McCabe, Colin. James Joyce and the Revolution of the Word. UK: Macmillan, 1978.

Marganiello, Dominic. Joyce's Politics. UK: Routledge, 1980.

Peake, C. H. James Joyce: The Citizen and the Artist. UK: Edward Arnold, 1977.

Reynolds, Mary T. Joyce and Dante. USA: Princeton UP, 1981.

Scott, Bonnie Kime. James Joyce. USA: Humanities Press International, 1987. 